8-11-2006

\title{
Video Cultures: Television Sociology in the "New TV” Age
}

Laura Grindstaff

Joseph Turow

University of Pennsylvania, jturow@asc.upenn.edu

Follow this and additional works at: https://repository.upenn.edu/asc_papers

Part of the Broadcast and Video Studies Commons, and the Communication Technology and New Media Commons

\section{Recommended Citation}

Grindstaff, L., \& Turow, J. (2006). Video Cultures: Television Sociology in the "New TV" Age. Annual Review of Sociology, 32 103-125. https://doi.org/10.1146/annurev.soc.32.061604.143122

This paper is posted at ScholarlyCommons. https://repository.upenn.edu/asc_papers/648

For more information, please contact repository@pobox.upenn.edu. 


\title{
Video Cultures: Television Sociology in the "New TV" Age
}

\begin{abstract}
We argue that the most significant and influential research on television over the past five decades positions the medium as a key site for addressing the complex interrelationship between culture and institutional/ organizational power. Granting that such work is theoretically and methodologically diverse, we employ an organizational frame that groups political-economic approaches on the one hand and cultural approaches on the other. Political-economic approaches largely attend to issues of power at a macro level, focusing on how ownership and control of television along with the organization of television production practices shape and influence content; cultural approaches focus more on the expressive and symbolic dimensions of television programming and reception. At the same time, contemporary changes in the medium threaten to make past research on television appear quaint and anachronistic. The industry's transformation of television into continually emerging sets of multifaceted digital-interactive technologies challenges researchers to draw enduring perspectives from the older work and assess how they apply to the new-media environment. Consequently, we suggest the term "video cultures" in lieu of "television sociology" as a way of capturing future trends.
\end{abstract}

10.1146/annurev.soc.32.061604.143122

\section{Keywords}

new media, political economy, programming, reception

\section{Disciplines}

Broadcast and Video Studies | Communication | Communication Technology and New Media | Social and Behavioral Sciences 


\title{
Video Cultures: Television Sociology in the "New TV" Age
}

\author{
Laura Grindstaff ${ }^{1}$ and Joseph Turow ${ }^{2}$ \\ ${ }^{1}$ Department of Sociology, University of California, Davis, California 95616; \\ email: lagrindstaff@ucdavis.edu \\ ${ }^{2}$ The Annenberg School for Communication, University of Pennsylvania, Philadelphia, \\ Pennsylvania 19104; email: jturow@asc.upenn.edu
}

Key Words new media, political economy, programming, reception

Abstract We argue that the most significant and influential research on television over the past five decades positions the medium as a key site for addressing the complex interrelationship between culture and institutional/organizational power. Granting that such work is theoretically and methodologically diverse, we employ an organizational frame that groups political-economic approaches on the one hand and cultural approaches on the other. Political-economic approaches largely attend to issues of power at a macro level, focusing on how ownership and control of television along with the organization of television production practices shape and influence content; cultural approaches focus more on the expressive and symbolic dimensions of television programming and reception. At the same time, contemporary changes in the medium threaten to make past research on television appear quaint and anachronistic. The industry's transformation of television into continually emerging sets of multifaceted digital-interactive technologies challenges researchers to draw enduring perspectives from the older work and assess how they apply to the new-media environment. Consequently, we suggest the term "video cultures" in lieu of "television sociology" as a way of capturing future trends.

\section{INTRODUCTION}

Sociological perspectives have been central to the study of U.S. television since its earliest days. What has television sociology taught us? We argue that the most significant and influential work on television over the past five decades positions the medium as a key site for addressing the complex interrelationship between culture and institutional/organizational power. For analytic purposes, such work may be classified as either political-economic or cultural. At the same time, we argue that contemporary changes in the medium threaten to make past research on TV appear quaint and anachronistic. What we traditionally call television is becoming an inseparable part of media streams that individuals encounter in everyday life and that they use to make sense of their worlds. Thus, we suggest that the term 
television sociology is too narrow to encompass the increasing interconnectedness of textual, audio, and audiovisual messages that characterize the contemporary media landscape. Rather than bracket out television from this stream, it makes sense to explore how it fits and what it means in the larger symbolic context that we call video cultures. The industry's transformation of television into continually emerging sets of multifaceted digital-interactive technologies challenges researchers to draw enduring perspectives from the older work and assess how they apply to the new-media environment. The changes also require media scholars to raise new sociologically informed questions about digital-interactive TV's contemporary relationships to culture and power.

Systematic academic study of television's social role over the past five decades has undoubtedly been driven by the medium's pervasiveness and centrality in the American home. In an early survey of TV's social impact, Leo Bogart (1956, p. 1) observed that "on the evening of March 7, 1955, one out of every two Americans was watching Mary Martin play 'Peter Pan' before television cameras. Never before in history had a single person been seen and heard by so many others at the same time." To Bogart, this phenomenon was evidence that television had become "a firmly established feature of American life" (p. 8). It was also clear to him that TV was a domestic feature of life; he noted its presence in "four out of five U.S. homes" (p. 8), and he ignored the medium's uses outside that milieu (in bars, for example). Bogart was a graduate of the program run by Paul Lazarsfeld and Robert Merton at Columbia University that had done much to establish mainstream academic discourse on mass media-newspapers, magazines, books, the movies, and especially radio - with its emphasis on the individual and interpersonal uses and effects of those technologies. In outlining the reasons for studying the particulars of television's role in U.S. society, Bogart and others drew on broad ideas about the media's cultural power that were engaging many thinkers of the day and that harked to the late nineteenth century.

Central among these ideas were concerns about the stability of European, British, and American societies in an age of political and social upheaval. Industrialization and urbanization were generating large, unorganized masses that seemed poised on the brink of dangerous action. Karl Marx and his followers attributed this development to the increasing gap between the owners of capital and the working classes, a gap that was destined to result in revolution and a redefinition of social relations. A different group of social philosophers led by Émile Durkheim and Frederick Tonnies blamed primarily the industrial age itself, not enduring class divisions. It was an age, they said, in which commercialization and specialization seemingly threatened the traditional roles that knit communities together (Durkheim's notion of mechanical solidarity) and encouraged reciprocal activities based on formal contracts rather than communal ties (Tonnies's notions of gesselschaft as opposed to gemeinschaft). A more conservative variation is evident in Gustav Le Bon's (1908 [1952]) treatise The Crowd, which argued that mass assembly encouraged violent, irrational behavior, threatening to overturn society's rational (and aristocratic) leadership. 
These streams of thought had major implications for understanding the role of media industries that was developing in the late nineteenth century. According to the Marxist perspective, the media formed the ideological superstructure that expressed the values of the capitalist social base. The enactment of capitalist beliefs across establishment media would not abate until revolution changed the base and instituted a new superstructure. The industrial age social philosophers, by contrast, saw the media as reflecting the tensions of the new era. Although often critical of the sensationalism that passed for journalism and literary works, they held out the possibility that mass media would benefit society. This more positive view was carried forward by scholars such as John Dewey and Robert Park (both of the University of Chicago), who believed that because the new technologies of communication reached so many so quickly, they could bring Americans together in ways that would encourage democratic thinking akin to town meetings of old (see Czitrom 1982). Park (1972), in particular, believed that properly managed mass media could help America create rational citizens (publics) as opposed to emotional, dangerous crowds. He argued, for example, that the immigrant press of the early twentieth century, far from keeping people tied to homeland customs, were socializing them en masse into the norms of mainstream U.S. life. These questions surface again in the contemporary moment in theorizing about the public sphere potential of television and other media.

The suggestion that mass media's significance lay in shared patterns of content faded somewhat with the decline of immigration in the 1920s and the rise of social concerns about the short-term effects of media messages-for example, of enemy propaganda on civilians, of movie sex and violence on children, of advertising on buying habits, and of radio coverage on political participation in elections. At the same time, Marxist analyses of media continued in various quarters and in various guises across the decades. Although the Marxist and Chicago perspectives are quite different, they both suggest that a medium's ability to present appealing content to millions of people more or less simultaneously is the starting point for caring about, and exploring, its social role.

Virtually from the start of television's commercial life in the late 1940s, academics saw that it would achieve an unparalleled centrality in society. Many agreed with Bogart (1956, p. 2) that "with no other form of impersonal communication has the sharing of experience been possible on so universal a scale and to so intense a degree as with television." This belief led media scholars to take television as a site in which key questions about the relationship between culture and power could be asked and explored. As we have noted, the resulting arguments have been theoretically and methodologically diverse; moreover, the best division is not necessarily between Marxist and non-Marxist perspectives. Critiques of the political and economic elements of power do, however, coalesce into a more or less coherent field that attracts some scholars more readily than others, whereas different but compatible streams of research take the complexities of culture and text as more useful nodes for understanding the medium's social importance. It 
makes some sense, then, to divide sociologies of television into the two approaches we highlight here: political-economic and cultural.

\section{PART I. POLITICAL-ECONOMIC PERSPECTIVES ON TELEVISION}

Research on the political economy of television focuses on the regimes that rule, regulate, supervise, and otherwise influence the medium's content. Exactly what is meant by the medium of television has varied by researchers and by the time period in which they have worked. The broadest notion underlying these writings is that television is an industry embedded within a broad media system and that both the industry and the system are closely tied to structures of power in society that have vested interests in the content.

Several points in the last sentence deserve elaboration. Although outsiders may view television primarily in terms of production - the creation of TV shows-the television industry is in fact also continuously engaged in the complex processes of distributing and exhibiting programming. Television networks such as CBS, Lifetime, and $\mathrm{HBO}$ and syndicators such as King World exercise their greatest industrial and cultural influence not just through making programs but also through their ability to implement the technical and marketing expertise to distribute those shows to exhibitors - local stations, cable operators, satellite firms - that then relay them to audiences in various locations. These activities are themselves tied to complex funding mechanisms that depend to varying degrees on national and local advertising, cable and satellite subscription fees from audiences, and ancillary revenues as widespread as deals with broadcasters outside the United States, DVD retail sales, and rentals by airlines. The amount of funding available from each of these sources depends on competitive developments in a media system that encompasses a panoply of media from newspapers to cell phones. So, for example, increased interest by marketers in advertising over the Internet and cell phones may lead them to reduce purchasing commercial time on traditional broadcast TV.

This sketch of a basic chain of activities only alludes to the complexities of the television industry's interactions with the larger social system, not the least of which is the production, sale, and marketing of consumer goods and services advertised on television. Not surprisingly, academic researchers with different political-economic models explore different facets of the industry and highlight different conclusions. At a macro level are analysts who see the TV industry as a key vehicle that corporate and government elites have used to shape public consensus in their direction (See Parenti 1992; McChesney 1992, 2004; Schiller 1999; Mosco \& Schiller 2001; Foster \& McChesney 2004). McChesney (1992) traces the definitive capture of television by these forces to the sharp conflict between educators and corporations from 1927 through 1935 about whether U.S. broadcasting should become primarily government- and foundation-supported or whether it should be a private, for-profit venture. The victory of corporate interests, he argues, 
involved differing notions of democracy and the role of media in a political system. On the one hand, reformers claimed that a self-governing democratic society should actively study and debate the various options for how best to organize its broadcast media, regardless of the outcome of this debate. Industry representatives, on the other hand, claimed that the market, left alone, was democratic, and no debate was necessary to justify its extension into broadcasting. Moreover, as McChesney (1992) writes, "merely debating the suitability of the market was [considered] undemocratic by this reasoning, to the extent that it might lead society to adopt nonmarket structures, which were presupposed as antidemocratic" (p. 34). McChesney's more recent work (1999, McChesney et al. 2005) moves his critique of corporate control forward into the new-media era, arguing that commercialism continues to transform and degrade the possibility for a truly democratic society despite utopian pronouncements about the liberating potential of the Internet and the several-hundred channel television universe.

Other scholars, too, have analyzed how established corporate and government interests influence the processes and outcomes of news and entertainment (Turow 1984, Golding et al. 1986, Grossberg et al. 1998). Schiller (1989) has examined how the media's commercial base has effectively privatized public culture by generalizing the corporate voice across the entire spectrum of cultural institutions, while for decades Bagdikian $(1983,2004)$ has chronicled the increasing concentration of media monopolies. Although not uncontested (see Gamson \& Latteier 2004), the proposition guiding Bagdikian's research on conglomerate ownership is that "the safest way to ensure diversity of opinion is diverse ownership" (see also Alger 1998; Aufderheide 1999; Bielby \& Bielby 1999, 2003). During roughly the same period, Edward Herman and Noam Chomsky (1988 [2002]) set forth a propaganda model of media operations that focuses more on media processes than on ownership. It argues that powerful media firms interface with other sectors of the society regarding ownership, management, and social networks in ways that prevent those firms from remaining analytically detached from the power elite and its interests. So, for example, if the U.S. news media are adversarial toward the U.S. government on foreign policy, institutional filters operate to ensure that the criticisms made generally stay within narrow bounds set by the U.S. political elite. In many ways, the work of the media scholars discussed here shares common ground with the macro sociological perspectives of class cohesion theorists such as Domhoff (1974) and Scott (1979), as well as bank hegemony theorists such as Mintz \& Schwartz (1985).

In recent decades, with the rise of multinational conglomerates such as Sony and Bertelsmann, attention has shifted to Western rather than just American players. Herbert Schiller was among the most notable researchers who carried the political-economy perspective about U.S. television into the international arena. His first book on the subject, Mass Communication and American Empire (Schiller 1969), argues that what differentiates the United States from other empires in history is its primary reliance on mass media rather than military to bring nations around the world into its fold. Published at the height of the Vietnam War, the 
book details the strong cooperation between U.S. business and government to promote the American commercial television system and its content throughout the world. Under rubrics such as democracy and global trade, Schiller argues, the United States spreads its cultural, political, and economic hegemony.

More culturally specific, interdisciplinary work on global television, although conceding the basic premise of Western cultural imperialism, nevertheless also attends to how the global television market is unpredictable and subject to a variety of forces outside corporate and political control, such as the existing cultural contexts of host countries as well as the growth of national/regional television production outside the West (see Miller et al. 2001, Parks \& Kumar 2003). Parks \& Kumar argue that global television cannot be analyzed exclusively in terms of an overarching theory but must be understood "through close examination of the television industries, programs, technologies, and audiences in specific cultural contexts" (Parks \& Kumar 2003, p. 6). A useful concept here is "asymmetrical interdependence" (Straubhaar 1991), which advocates examining the dynamics of a particular nation's media industries, including relations between domestic and international elites, policies of state intervention, and entrepreneurial competition, in light of its relative degree of subordination in the world economy.

Central to the perspectives presented so far is a concern with television's role in shaping the nature of public discourse (whether locally or globally) in ways that naturalize and solidify established political and economic power. A related vein of research focuses more explicitly on the role of the media in shaping the nature of the public sphere within given societies (see Habermas 1989, Garnham 1990, Livingstone \& Lunt 1994, Crane 1995, Dahlgren 1995, Keane 1995, Cunningham 2004). As Dahlgren (1995) argues, the media have become such a broad force in society that, like it or not, they now play an important role in citizenship formation, and the nature of that citizenship is ambiguous, fragmented, and difficult to categorize (see also Kellner 1995).

For Habermas, the public sphere is a realm in which critical issues of the day can be raised and debated unconstrained by institutions of state sovereignty or the market relations of the economy. At its core, the concept is concerned with communicative action as both place and process; the potential for a public sphere exists when ordinary citizens come together and negotiate consensus over issues through a free and rational exchange of views. The press was considered a key institution in facilitating the development of a bourgeois public sphere in eighteenth century Europe, and while a number of developments since, including the rise of mass media, big business, and polling, have rendered the classic Habermasian concept largely anachronistic, media scholars today still debate the potential of broadcast and Internet technologies to develop (or inhibit) new types of mediated public spheres. Garnham (1990), for example, suggests that public service broadcasting comes closest to Habermas's original model because its relative autonomy from market-driven forces enables a less partisan, more universalistic politics. Others challenge or qualify this conclusion, noting that public broadcasting in both Europe and the United States has become more commercialized over time 
(Dahlgren 1995; Keane 1995; Hoynes 1994, 2002) and that U.S. public television prioritizes corporate and governmental sources in its news and public affairs programming (Hoynes 2002).

Inevitably, discussions of television and the public sphere become coterminous with discussions of the public sphere in the context of all media. Keane (1995), Crane (1995), and Cunningham (2004) all argue that we are experiencing a deterritorialization of public life through media and new communications technologies; consequently, there is no such thing as a public sphere, but rather multiple public spheres-Cunningham (2004) uses the term "sphericules" - and they are not exclusively housed within state-protected public service media or tied to traditional forms of political engagement, but rather encompass such diverse phenomena as radio and television talk shows, computer networking, citizens' initiatives, newspaper circulation, indigenous satellite broadcasting, webcasting, ethnic-specific community media, and children playing video games. This position is consistent with the critiques of Habermas issued by Garnham (1990), Curran (1991), Fraser (1990), Calhoun (1996), and Negt \& Kluge (1993), all of whom argue in different ways that Habermas's ideal type of rational debate neglected the development of plebeian public spheres and excluded whole categories of people on the basis of gender, race, sexuality, lack of property, and social status. For these authors, the current crisis of representational democracy signaled by the apparent mass rejection of politics is in part a crisis of the traditional institutions of the bourgeois public sphere: the party, the union, the town hall, and so forth. Accordingly, reasserting the primacy of these institutions may be less productive than rethinking the nature of the public sphere itself and what kind of politics can take place there. One of the more interesting contemporary sites for this endeavor is reality TV, which has moved from the periphery to the core of prime-time programming and whose marketing and distribution extends beyond the confines of television per se to encompass web, Internet, video, and cell phone technologies.

Closely aligned with the political-economy framework is the production-ofculture perspective on television, which serves as a bridge to the cultural approaches covered in Part II of this review, and indeed might have been placed there instead. We employ it here, however, because some of the key criticisms leveled at politicaleconomy scholars-that media ownership patterns and the content of news and entertainment are not related in any linear or consistent way, or that politicaleconomy scholars fail to track empirically the very processes they are inferring (for a review, see Klaehn 2002) — are at least partially addressed by production-ofculture research. This research seeks to understand television as a social institution in which work is formally organized to produce particular types of programming that frame social reality in particular ways, ways that typically uphold established power arrangements.

A recent review essay by Peterson \& Anand (2004) suggests that the analytic thrust of the production-of-culture tradition is a focus on "how the symbolic elements of culture are shaped by the systems within which they are created, distributed, evaluated, taught, and preserved" (p. 311). Production-of-culture scholars 
examine "the processes of symbol production" using "the tools of analysis developed in the study of organizations, occupations, networks, and communities" (Peterson \& Anand 2004, p. 312), with the underlying assumption that the production of media and forms of expressive culture share common ground with other institutionalized work settings (see Hirsch 1977, 2000). Howard Becker's (1982) Art Worlds is a canonical example, but the empirical studies within this tradition cover a range of cultural phenomena, including, in addition to media systems, science laboratories (Crane 1972), the fashion industry (Crane 2000), art museums and symphony orchestras (DiMaggio 1982), book publishing (Coser et al. 1982, Powell 1985), country music (Peterson 1997), popular music (Peterson \& Berger 1975, Frith 1978), and gastronomy (Ferguson 1998).

In production-of-culture studies of television, the main concern is with the nature of the reality that is constructed and disseminated by the media, as well as with the processes by which this construction takes place. Questions of power center on who has access to the media, who/what shapes professional media practices and values, and how these practices and values promote certain versions of reality over others, questions clearly relevant to political-economy theorists. Because academics tend to view the news agenda as more related to issues of democracy and civic engagement than entertainment, most research of this kind has been on the nature of national and local television news. Gans's (1979) now-classic Deciding What's News is a good illustration. Focusing on the top tier of the established news industry in the United States, Gans is concerned with the nature of national news media and the dynamics of news selection and preparation. He sees news as a system of power, one interlocked with a range of other professions and institutions (legal, political, economic) and one resulting from different and sometimes competing considerations-sources, audiences, and organizational standards. Overall his findings support the view that the major media institutions reinforce rather than weaken the established social order not because of a conspiracy between journalists and corporate or political elites, but because professional standards and organizational practices put journalists in ready contact with economically and politically powerful sources who have considerable influence in deciding what's news. Access to the media, Gans insists, reflects the hierarchical social structure outside the newsroom.

Other studies of newsmaking concur that standard reportorial practice legitimates those with institutional power even as it allows occasional challenges to that power (Epstein 1973, Sigal 1973, Molotch \& Lester 1974, Altheide 1976, Tuchman 1978, Fishman 1980, Gitlin 1980, Kannis 1991). As Tuchman (1978, p. 4) puts it, "news is an ally of legitimated institutions." For her, it is also a way of applying the sociology of knowledge to an analysis of media, for she sees news organizations as having considerable power to "create, impose, and reproduce social meanings - to construct social reality" (p. 208). Such conclusions are not only consistent with the strands of political-economy research discussed above (particularly those emphasizing the interdependence of political, business, and media elites in shaping the contours of public issues and public debate), but they are also 
compatible with the general thrust of agenda-setting research in that greater access to media by elites translates into greater opportunity to construct reality for specific audiences and potentially to influence what topics audiences find salient and important (for an example of agenda-setting research, see Iyengar \& Kinder 1987, Iyengar 1991). In varying ways, in various locales, and with varying degrees of texture, the production-of-culture perspective on news supports Gans's conclusion that "news is about the economic, political, social and cultural hierarchies we call nation and society" (Gans 1979, p. 284).

Sociological studies of television news thus justify their importance partly through the assumption that TV news — as opposed to all TV programming - helps to set society's agenda about world concerns. At the same time, however, critics are writing about a shift in the American media from serious hard news to softer, more entertainment-oriented fare and about the delivery of news through entertainment formats. For example, topical comedy programming aimed at young adults such as The Daily Show on Comedy Central, Bill Maher's programs on HBO, and David Letterman's monologues on CBS might well be considered sources of news insofar as they are the vehicles through which millions of people, especially young people, learn about significant issues of the day (see Delli Carpini \& Williams 1996, 2001). This development reinforces the point made long ago by Gerbner \& Gross (1976) that all genres of content consist of stories that teach, and it is also consistent with the notion that we live in a world characterized by a multiplicity of mediated public spheres rather than a single ideal type. As Keane (1995) observes, music, opera, sport, painting, and dancing all were among the forms of communication advancing the growth of public life in eighteenth century Europe; consequently, "there is. . no principled reason... why their late-twentieth century popular counterparts - the rambunctiousness of MTV's annual video awards, the simulated uproar of Ricki Lake shows, or the hypertext of video games - should not be considered as legitimate potential media of power conflicts" (Keane 1995, p. 18).

Nevertheless, studies of television entertainment within the production-ofculture tradition are relatively rare. There is research on Hollywood producers' constructions of their audience (Cantor 1971); on the institutional and interpersonal forces shaping prime-time entertainment (Gitlin 1983); on the relationship between advocacy organizations and TV content (Montgomery 1989); on the influence of the medical system on the "doctor show" formula (Turow 1989); on the routines that govern casting (Turow 1978) and that govern programmers' decisions about new series (Bielby \& Bielby 1994); on the construction and framing of sexual nonconformity on daytime talk shows (Gamson 1998); on the class dynamics of "airing dirty laundry" on talk shows (Grindstaff 2002); and on the changing representations of blackness in American television (Gray 1995). Although some of this work (that of Gamson, Grindstaff, and Gray) may fit more comfortably into the cultural approaches discussed in Part II below, the rest draws on organizationalindustrial perspectives solidly located within the production-of-culture corner of the political-economy tradition. Turow (1989), for example, employs a resourcedependence model to understand the symbiotic relationship between physician 
leaders and TV producers. Cantor (1971) connects her study to the sociology of work. And Bielby \& Bielby (1994) apply institutionalist theories of organizations to examine "how decision makers operating under conditions of ambiguity and uncertainty cope with contradictory commercial and aesthetic assessment criteria" (p. 1288). Explicitly or not, such studies emphasize how social and institutional power gets translated through the organizational and interpersonal activities of the production process.

\section{PART II. CULTURAL APPROACHES TO TELEVISION}

Although political-economic approaches to television are certainly cultural in the sense that marketing strategies, corporate business practices, work routines, and governmental and regulatory policies have cultural implications and are part of larger cultural systems of meaning, for our purposes here we use the term cultural to refer to those scholarly perspectives that give analytic emphasis to the expressive and symbolic dimensions of television, whether in relation to theories of television and society, issues of programming and representation, contexts of reading and reception, or some combination thereof. Such scholarship is extraordinarily diverse and cross-disciplinary, much of it now going by the name television studies (see Allen \& Hill 2004); consequently, we make no claims to comprehensiveness but rather aim to explore some key themes and the way they play out in sociologically relevant research.

Contemporary cultural theory about television's role/place in modern society has been, at least in part, a reaction to the technological determinism of some of the medium's early critics, in which culture-level arguments are made about television's effects regardless of social or historical specificity. Well known among these critics are McLuhan (1964), who posited a celebratory view of electronic media as enabling a global village, and Adorno (1957), who, in concert with other mass culture theorists, denounced television for insinuating the capitalist mode of production into people's everyday leisure experiences, thereby diminishing the capacity for critical, reflexive engagement with the world (see also McDonald 1968; for an updated version, see Postman 1985). ${ }^{1}$ Baudrillard (1983), too, took a more or less deterministic stance, arguing that the primary effect of television and other media, regardless of content, is to substitute a realm of hyperreal representation (simulacra) for the world itself.

\footnotetext{
${ }^{1}$ In Amusing Ourselves to Death, Postman (1985) casts television as a threat to the intellectual health of society because it reduces serious discourse to meaningless banalities. In his words, "the problem is not that television presents us with entertaining subject matter but that all subject matter is presented as entertaining. . it is in the nature of the medium that it must suppress the content of ideas in order to accommodate the requirements of visual interest; that is to say, to accommodate the values of show business" (pp. 87-88, emphasis added).
} 
Against this backdrop has emerged a less deterministic body of theorizing about the power of television to shape/influence the character of modern societies in which different thematic clusters can be identified. Some scholars are concerned with the role of television in shaping time/space relationships across social, economic, and political domains (Meyrowitz 1985, Katz \& Dayan 1992, Silverstone 1994, Morley 2004). Others focus on the ideological/hegemonic dimensions of the medium, both in reproducing established power relations (Gitlin 1978) and in negotiating cultural contradictions (Williams 1974, Newcomb \& Hirsch 1983, Kellner 1990). Still others focus on various aspects of television as discourse, as a social field in which the delivery of information is narrowly and unjustly constrained (Bourdieu 1998), as a commercial tool promoting spectacular consumption (Miller 1988), as an aesthetic force shaped by specific industrial/technological developments (Caldwell 1995, 2004), and as a form of popular culture in which struggles over textual/cultural meanings take place (Newcomb 1974, Williams 1974, Fiske \& Hartley 1978, Hall 1980, Kaplan 1983, Fiske 1987).

Two early volumes in particular had a strong influence on the framing of television as popular rather than simply mass culture, that is, as a site where meaning is made and not simply given or assumed. ${ }^{2}$ One was Horace Newcomb's (1974) TV: The Most Popular Art, which emphasized the complexity of television formulas (particularly with regard to the literary elements of plot, character, and genre) as well as the multiple levels of meanings available to viewers. The other was Raymond Williams's (1974) Television: Technology and Cultural Form, which set the stage for an explosion of media research in the UK and abroad, much of it associated with cultural studies. Television, Williams argues, "is at once an intention and an effect of a particular social order" (p. 128). Although the social order is still structured by inequalities of power, Williams emphasizes contradiction and multiplicity in the development of television, its possibilities for serving both dominant and marginal interests. Aside from obvious affinities to the work of Stuart Hall and others affiliated with British cultural studies, one can see here key affinities to U.S. scholars working in different but related traditions-Kellner's (1981) critical institutional assessment of American network television as an inherently contradictory system, and the work of Newcomb \& Hirsch (1983), which posits a cultural forum model of television. In this model, television is the cultural terrain

\footnotetext{
${ }^{2}$ Grindstaff (2000) distinguishes between mass culture and popular culture in the following way: "mass culture - that is, industrially-produced culture - consists of the texts, objects, and relations of the culture industries; popular culture is what people make of those texts, objects and relations. For example, the culture industry produces many television programs, but how people understand them and what role television plays in everyday life is not self-evident or necessarily given in the programs themselves. Mass culture is the objective repertoire from which people create subjective, popular meanings-albeit meanings inevitably circumscribed in key ways by the repertoire itself. This meaning-making not only acknowledges an active dimension to consumption, it requires us to consider popular culture in a more local, personal, and political sense" (p. 533).
} 
on which the metaphoric fault lines of American society are expressed and worked through, not by imposing a monolithic or dominant viewpoint but by exploring ideological contradictions through multiple and competing perspectives (see also Spigel 1992).

Williams is probably best known for his concept of flow-the fluid movement of fragmented texts across time and space, which constitutes an overall mode of experience. As Spigel points out in her excellent introduction to the 1992 reprint of Williams's book, it was this concept that most influenced scholars (particularly in the humanities) who were hungry for ways of thinking about television as something other than simply discrete programs to be analyzed or a capitalist institution to be condemned. It forced a consideration, even if at a largely hypothetical level, of how the cultural form of television worked on people and structured their experience aside from specific issues of message or content (see Modleski 1982, Kaplan 1983, Fiske 1987). The concept of flow clearly influenced the essay by Newcomb \& Hirsch (1983) mentioned above, which theorizes how viewers create their own patterns of flow by selectively attending to different combinations (or strips) of programming, and it helped set the stage for Lembo's (2000) important theory on the "sociality of television use," which analyzes how people watch television and how it fits into their everyday relationships and routines.

More obliquely, Williams's concept of flow can be said to inform John Caldwell's (1995) Televisuality: Style, Crisis, and Authority in American Television, insofar as Caldwell is arguing that postnetwork television has adopted a new look to engage its audiences, a stylized, self-conscious, excessive tele-aesthetic driven largely by changes in technology and high-stakes market relations. For Caldwell, it is not so much the flow of television's content per se as its aesthetic reconfiguration across a range of genres and formats that has generated a new recipe for hailing audiences within a changed industrial context. Today, developments such as webcasting, HDTV, and digital filter technologies such as $\mathrm{TiVo}^{3}$ are prompting a reconsideration of the relationship between viewer and content. As Uricchio (2004, p. 180) observes, flow has been used to describe "economies of time and consciousness in the form of the viewer's encounter with programming;" consequently, as television converges with the computer, the nature of this encounter will inevitably change, as will the power of new commercial sectors specializing in viewer-programmer interfaces (see also Boddy 2004, Caldwell 2004, Parks 2004).

Grand theorizing aside, the volume of contemporary scholarship that can be subsumed under cultural approaches to television is enormous, encompassing work across a range of disciplines (cultural studies, film studies, American studies, sociology, anthropology, and communications) and various facets and dimensions of the medium (programming/content, reception, social/historical context). Even

\footnotetext{
${ }^{3} \mathrm{TiVo}$ is a relatively new digital filtering technology that provides both an extensive guide to programming and the capacity to search, record, store, and retrieve specific programs.
} 
anthologies within the burgeoning field of television studies are beyond cataloguing (for a select few, see Allen 1987, Mellencamp 1990, Spigel \& Mann 1992, Haralovich \& Rabinovitz 1999, Newcomb 2000, Miller et al. 2001, Parks \& Kumar 2003, Allen \& Hill 2004, Spigel \& Olsson 2004). And although sociologists are not well represented in these anthologies, the study of media/television having remained relatively marginal within the discipline as a whole, there is much sociologically relevant work. The days when humanistic scholars merely performed readings of individual television programs while social scientists took on real research into media production, consumption, and industrial relations are largely gone. This is not to say that general disciplinary differences no longer exist, but rather that they are less marked (and less relevant) than they once were.

The cross-disciplinary nature of television studies makes it difficult to map, however. Although admittedly simplistic, a distinction we choose to employ here is between cultural scholarship that focuses on television programming (including content/genre/representation, industry discourse, social and historical context, etc.) and scholarship that focuses on the reception/uses of television-what people do with television, how they think and talk about it, and how it relates to other aspects of their lives. We recognize, of course, that some scholars admirably attend to both areas simultaneously (see Harrington \& Bielby 1995, Shattuc 1997, Gamson 1998, Mayer 2003), and, moreover, that industry knowledge about audiences very much informs programming decisions and strategies, making the separation of reception from programming necessarily problematic. But the distinction is useful analytically nevertheless, drawing attention to relative differences in foci between textual/discursive approaches and ethnographic or interview-based ones.

Studies of television programming share a commitment to examining the spaces, modes, and representations/content of television in their historical and cultural specificity. Whether the focus is on specific genres (Cantor 1983, Allen 1985, Neale \& Krutnik 1990, Timberg et al. 2002, Couldry 2004), the "politics of representation" (Hamamoto 1994, D'Acci 1994, Gray 1995, Kendall 2005), industry discourses on programming and marketing (Byars \& Meehan 2000, Boddy 2004, Magder 2004), television's relationship to citizenship and nationalism (Hartley 1999, Curtin 2004), the use of television to regulate the experience of time in public places (McCarthy 2001), or the popular narratives that first framed the meaning of television for postwar American families (Spigel 1992), this work employs textual, archival, and/or discourse analysis in the service of understanding how television works in/on society. This scholarship is both cultural and critical, seeing television as a commercial institution that, in producing programming, also produces (and proscribes) social representations and ideas about the world, particularly as they relate to notions of power, place, and identity (race, class, gender, sexuality, and so forth). Although empirical, this work is, like its objects of study, fluid, mobile, and wide-ranging; as a result, it has been at the vanguard of theorizing about the new-media era of television, or what Spigel \& Olsson (2004) call "television after TV," in both domestic and global contexts. 
Although more could be said about cultural approaches to programming, we turn now briefly to the complementary (and interdependent) arena of reception/use, an equally varied and diverse field of inquiry that has a relatively stronger ethnographic thrust. Of course, reception is not reducible to the act of watching television. As Allen \& Hill (2004, p. 457) observe, reception also entails "talking about what we have seen/are about to see, being addressed as a viewer by television's programs and scheduling practices (late afternoon for kids, late night for adults), and encountering television through other media (the press, official or fan-sponsored websites)."

Generally speaking, cultural studies of reception have rejected the notions that, on the one hand, the masses are easily manipulated and controlled by the media and, on the other hand, that rational individuals consume selected media for particular, identifiable, and measurable reasons. Instead, scholars have adopted a more anthropological perspective on audiences as embedded in cultures and communities; from this perspective, people are not reducible to television viewers, and television is not simply received but used as a material resource in everyday life. The conceptual influence of Hall's (1980) foundational essay "Encoding/Decoding" is evident here. Hall theorized the media-audience circuit as a reciprocal (though not equal) one: Whereas the culture industries may be hegemonic, working to secure social and political consensus, viewers and audiences may respond to, and interpret, media texts in a variety of ways. Hence, Fiske's (1987) preference for the term "reader" over "audience," as the latter implies "a homogeneous mass of people who are all essentially identical, who received the same messages, meanings, and ideologies from the same programs and who are essentially passive" (p. 16; see also Jenkins 1992). Of course, the notion of the active or resisting reader can be carried to an extreme (particularly when resistance to mediated texts is accorded considerable political significance), but the larger point is that the reception of television is a potentially complicated business. Moreover, the contours of reception continue to shift as more studies are carried out and more types and levels of influence are considered. Currently scholars are less interested in whether television is oppressive or liberating than in what television means to people and how it intersects with other powerful institutions structuring contemporary life.

Leaving aside theoretical explorations of how media texts position or address viewers, three broad types of reception study have tended to dominate the cultural field. One type investigates the decoding process by focusing on viewer interpretations of a specific program, genre, or set of programs (Morley 1980, Ang 1985, Liebes \& Katz 1990, Livingstone 1990, Press 1991, Jhally \& Lewis 1992, Gripsrud 1995, Hill 2002, Manga 2003). Liebes \& Katz (1990), for example, had groups from five different cultures watch and discuss Dallas, thereby revealing the importance of distinct national/cultural repertoires to interpretations of the show. Jhally \& Lewis (1992) interviewed viewers of The Cosby Show and concluded that the show, among other things, encouraged "enlightened racism." Both Press (1991) and Manga (2003) highlight class differences among women with regard to 
reading strategies and modes of involvement, Press using depictions of prime-time femininity as her vehicle and Manga using tabloid daytime talk shows.

A second type of study examines the activities and practices of television fans, both in real and virtual space. Although scholarship on the organized activities of science fiction fans is perhaps best known (see Jenkins 1992, Bacon-Smith 1992, Tulloch \& Jenkins 1995), scholars have examined fan activity surrounding a wide range of programming (see Tulloch 2000, Hills 2002 for good overviews), including, most recently, various types of reality TV - in part because of the considerable online fan activity generated by the genre (e.g., LeBesco 2004, Wilson 2004). In our view, Harrington \& Bielby's (1995) study of soap opera fans remains one of the most nuanced and comprehensive analyses of both the public and private dimensions of fandom. In their research, the fan world is constructed not only by organized social activity (on the part of the soap industry as well as fans themselves), but also by the private, personal engagement of dedicated viewers who express their enthusiasm in less formalized ways.

A third type of reception study examines the broader domestic (and sometimes public) context of television use/consumption in everyday life (Hobson 1982, Morley 1986, Palmer 1986, Gray 1992, Lull 1990, Gauntlett \& Hill 1999, Lembo 2000, McCarthy 2001, Fisherkeller 2002, Mayer 2003). On the whole, this work examines who watches television, the various conditions under which watching occurs (when, where, why, how), and how television use intersects and overlaps with other aspects of daily life. Analytic foci include the gendered use of technology within the family (Morley 1986, Gray 1992), the unique ways that children relate to television (Palmer 1986, Buckingham 1993), the communal functions of television viewing among Mexican American youth (Mayer 2003), and the deployment/reception of television in public settings such as waiting rooms, airports, bars, and retail spaces (McCarthy 2001).

Together with a limited subset of fan studies (e.g., Bacon-Smith 1992, Gillespie 1995), this third tier is most often identified as ethnographic, despite the fact that extended interviews and short-term encounters are more commonly employed than is sustained fieldwork. A classic ethnographic approach is more easily applied to television production (e.g., Grindstaff 2002) than to television reception, reception being a more fluid, geographically dispersed, and privatized phenomenon (see Radway 1988, Morley \& Silverstone 1990, Ang 1996, Seiter 2000). Not only is it is awkward to enter people's homes and watch them watch television, but television use cannot easily be separated from the rest of everyday life. As Ang (1996, p. 68) observes, "the activity so often simplistically described as 'watching TV' only takes shape within the broader contextual horizon of a heterogeneous and indefinite range of domestic [and, we would add, public] practices." Given this, Fisherkeller's (2002) ethnographic account of television and American adolescents is especially noteworthy. An anthropologist, Fisherkeller explores the meanings, uses, and influences of television culture in the lives of American youth as they play out in the varied contexts of family, school, and peer group. 
And yet, like everything else about television, the reception/uses of television are undergoing dramatic shifts. Television is present not only in the home but in all manner of public locations, where it is used not only for entertainment/distraction but also for surveillance and social control. People not only receive television via cable, satellite, and the Internet, they can wear it on their bodies in the form of cell phones and personal digital video recorders (PVRs). Just as there are multiple forms of television, there are also multiple ways of engaging it (watching live images versus recorded ones, playing video games, editing camcorder footage, listening to music, etc.). To quote Spigel $(2004$, p. 6), "as images multiply on a variety of delivery systems and platforms, who knows what audiences are seeing-much less thinking-anymore." Of course, changes in television do not affect everyone equally; they create further opportunities for generating inequalities of access and use on the basis of age, race, gender, and, especially, social class (see Fox 2005).

\section{LOOKING TO THE FUTURE}

In this last section, we discuss a number of potential research areas that deserve increased attention, despite the volumes of scholarship devoted to television over the past few decades. Especially needed are close studies of industry processes. Much of the industry literature about U.S. television focuses on broad conceptual considerations, discussions of programming content, or large-scale ownership patterns and their implications. Relatively few contemporary studies examine the ways people actually carry out their work in the TV industry. Of process-oriented studies that do exist, those examining news programming predominate over explorations of other forms-for example, entertainment, sports, or advertising (for exceptions, see Gamson 1998, Grindstaff 2002). Moreover, most detailed studies of television production concentrate on the process of creating content, while the dynamics of distribution and exhibition, critical aspects of the activity chain that brings programming to Americans, lie virtually unexamined.

Increased research on television processes is crucial for seeing whether and how propositions about the medium's political and cultural power (inferred by scholars from ownership patterns, organizational linkages, and content) become established, get reinforced, and sometimes get challenged and toppled. What organizational and interorganizational activities reinforce the social representations that appear on TV? How do news events make their way into fictional programming, and with what ideological implications? How do advertisers' concerns about the latest trends influence the content and delivery of commercials? How does programmers' awareness of advertisers' goals influence the creation of TV schedules, and thus the categories of content, on various networks? What economic, political, and social concerns influence the way cable and satellite firms arrange the menus - the flow_of programming they present to their audiences?

These questions merely skim the surface of the myriad issues that stand open to interrogation by sociologists. Indeed, it is puzzling why so little research has 
addressed them. Possible factors might be the difficulty (or the assumed difficulty) of gaining access to media organizations, lack of knowledge of the inner workings of the industry, and (particularly in the case of television entertainment) a concern that one's academic colleagues will consider the research trivial. Such obstacles are real enough, but they are not insurmountable. In particular, there is nothing trivial about studying the creation, distribution, and exhibition of television entertainment, as entertainment shapes the contours of our culture as much if not more than news. Moreover, there is considerable overlap and cross-pollination between entertainment, broadly conceived, and traditional forms of news and public affairs programming; indeed, entertainment formats are increasingly becoming vehicles for news and vice versa. To be sure, more explicit theory-building might also help legitimate the study of entertainment media in academic circles, as there have been few theoretical advances in analyses of production practices since the flurry of newsmaking studies in the 1970s.

Within both political-economic and cultural frameworks, there is also much work to be done on television in the new-media age. As we have noted, new technological, industrial, and social developments at the turn of the twenty-first century are continually broadening the places that people come into contact with the medium and its content. The explosion of cable and satellite TV beginning in the mid-1980s marked a sea change in the number of television channels most Americans received; by 2005, the average U.S. home received 100 channels. They received additional television via computer website streams, on hand-held DVD players, through audio Internet podcasts, on mall and airport monitors, and on cell phones. Television now includes phenomena such as videogames, nonindustrially produced videos available over the web, and snippets of video material linked to online textual discussions (the online New York Times, for example, is no longer a text-only newspaper). Most profoundly, perhaps, the new developments include computer-driven interactivity-situations in which viewers can respond to programs in real time. Such interactivity has facilitated the ability of marketers to compile databases of information about viewers' activities and video interests. The storage of viewer preferences has also led marketers to develop technologies that customize portions of content-including advertisements- to fit the perceived interests of different audience segments, or even individual audience members (see Turow 2005, 2006). This tracking and customization of television use based on continually updated databases raises questions about privacy, price discrimination, and other forms of industrial redlining that may privilege certain people who use television in certain ways-questions about power and culture that, until quite recently, hardly applied to the medium.

In the face of these developments, the very definition of television begins to blur or stretch, as new phenomena intrude on traditional program genres, locales, and intellectual concerns. Researchers must rethink the notion that television is primarily a domestic medium linked to a particular technology. In fact, new developments raise the issue of what television means, and whether television sociology as a term or arena of study is either useful or possible. We suggest that the term 
is too narrow to encompass the increasing interconnection of text, audio, and audiovisual materials that are becoming the hallmark of media in the twenty-first century. Rather than bracket out what we traditionally call television from the larger media stream of which it is a part, it makes sense to explore the various dimensions of audiovisual production, distribution, programming, and reception within the whole of the symbolic environment that we call video cultures.

Understood broadly, approaching television through the lens of video cultures will lead researchers to reexamine traditional questions about ownership and control, industry practices, content and representation, and audiences in the context of new cross-media relationships. Scholars will find enduring issues of political, economic, and cultural power; of genres, representations, and textual flow; of audience response and resistance. They will also see how the new digital age, where television is embedded in virtually all media, yields important new entry points into issues that are crucial to understanding the changing, and increasingly stratified, society in which we live.

\section{ACKNOWLEDGMENT}

The first author wishes to acknowledge Kim Ebert for her invaluable assistance in researching materials for this review.

\section{The Annual Review of Sociology is online at http://soc.annualreviews.org}

\section{LITERATURE CITED}

Adorno T. 1957. Television and the patterns of mass culture. In Mass Culture: The Popular Arts in America, ed. B Rosenberg, DM White, pp. 474-88. New York: Free Press

Alger D. 1998. Megamedia. Lanham, MD: Rowman \& Littlefield

Allen RC. 1985. Speaking of Soap Operas. Chapel Hill: Univ. N. C. Press

Allen RC, ed. 1987. Channels of Discourse: Television and Contemporary Criticism. Chapel Hill: Univ. N. C. Press

Allen RC, Hill A, eds. 2004. The Television Studies Reader. London/New York: Routledge

Altheide DL. 1976. Creating Reality: How TV News Distorts Events. Beverley Hills, CA: Sage

Ang I. 1985. Watching Dallas: Soap Opera and the Melodramatic Imagination. London: Methuen

Ang I. 1996. Living Room Wars: Rethinking
Media Audiences for a Postmodern World. London/New York: Routledge

Aufderheide P. 1999. Communication Policy and the Public Interest. New York: Guilford

Bacon-Smith C. 1992. Enterprising Women: Television Fandom and the Creation of Popular Myth. Philadelphia: Univ. Penn. Press

Bagdikian BH. 1983. Media Monopoly. Boston: Beacon

Bagdikian BH. 2004. The New Media Monopoly. Boston: Beacon

Baudrillard J. 1983. In the Shadow of the Silent Majorities. New York: Semiotext(e)

Becker HS. 1982. Art Worlds. Berkeley/Los Angeles: Univ. Calif. Press

Bielby W, Bielby D. 1994. "All hits are flukes": institutionalized decision making and the rhetoric of network prime-time program development. Am. J. Sociol. 99(5):1287-313

Bielby W, Bielby D. 1999. Organizational mediation of project-based labor markets: 
talent agencies and the careers of screenwriters. Am. Sociol. Rev. 64:64-85

Bielby W, Bielby D. 2003. Controlling primetime: organizational concentration and network television programming strategies. J. Broadcast. Electron. Media 47(4):573-96

Boddy W. 2004. Interactive television and advertising form in contemporary US television. See Spigel \& Olsson 2004, pp. 11332

Bogart L. 1956. The Age of Television. New York: Ungar

Bourdieu P. 1998. On Television. London: Pluto

Buckingham D. 1993. Children Talking Television: The Making of Television Literacy. London: Falmer

Byars J, Meehan E. 2000. Once in a lifetime: constructing 'the working woman' through cable narrowcasting. See Newcomb 2000, pp. 1414-68

Caldwell JT. 1995. Televisuality: Style, Crisis, and Authority in American Television. New Brunswick, NJ: Rutgers Univ. Press

Caldwell JT. 2004. Convergence television: aggregating form and repurposing content in the culture of conglomeration. See Spigel \& Olsson 2004, pp. 41-74

Calhoun C. 1996. Social theory and the public sphere. In The Blackwell Companion to Social Theory, ed. BS Turner, pp. 429-70. Oxford: Blackwell

Cantor MG. 1971. The Hollywood TV Producer: His Work and His Audience. New York: Basic Books

Cantor MG. 1983. The Soap Opera. Beverly Hills, CA: Sage

Coser L, Kadushin C, Powell W. 1982. Books: The Culture and Commerce of Publishing. New York: Basic Books

Couldry N. 2004. Teaching us to fake it: the ritualized norms of television's "reality" games. See Murray \& Ouellette 2004, pp. 57-74

Crane D. 1972. Invisible Colleges: Diffusion of Knowledge in Scientific Communities. Chicago: Univ. Chicago Press

Crane D. 1995. Reconceptualizing the public sphere: the electronic media and the public. In Societies Under Construction: Identi- ties, Conflicts, Differences (Proc. Gen. Conf. Swiss Soc. Sci., Berne, Switz.), ed. C Honegger, J Gabriel, R Hirsig, J Pfaff-Czarnecka, E Poglia, pp. 175-94. Zürich, Switz.: Seismo

Crane D. 2000. Fashion and Its Social Agendas. Chicago: Univ. Chicago Press

Cunningham S. 2004. Popular media as public "sphericules" for diasporic communities. See Allen \& Hill 2004, pp. 151-61

Curran J. 1991. Rethinking the media as a public sphere. In Communication and Citizenship: Journalism and the Public Sphere, ed. P Dahlgren, C Sparks, pp. 27-57. London/New York: Routledge

Curtin M. 2004. Media capitals: cultural geographies of global TV. See Spigel \& Olsson 2004, pp. 270-302

Czitrom D. 1982. Media and the American Mind: From Morse to McLuhan. Chapel Hill: Univ. N. C. Press

D'Acci J. 1994. Defining Women: Television and the Case of Cagney and Lacey. Chapel Hill: Univ. N. C. Press

Dahlgren P. 1995. Television and the Public Sphere: Citizenship, Democracy, and the Media. Thousand Oaks, CA: Sage

Delli Carpini M, Williams B. 1996. Constructing public opinion: the uses of fictional and nonfictional television in conversations about the environment. In The Psychology of Political Communication, ed. A Crigler, pp. 14975. Ann Arbor: Univ. Mich. Press

Delli Carpini M, Williams B. 2001. Let us infotain you. In Mediated Politics, ed. L Bennett, R Entman, pp. 160-81. New York: Cambridge Univ. Press

DiMaggio P. 1982. Cultural entrepreneurship in 19th-century Boston: the creation of an organizational base for high culture in America. Media Cult. Soc. 4(1):33-50

Domhoff D. 1974. Bohemian Grove and Other Retreats. New York: Harper \& Row

Epstein E. 1973. News From Nowhere. New York: Random House

Ferguson PP. 1998. A cultural field in the making: gastronomy in nineteenth century France. Am. J. Sociol. 104:597-641 
Fisherkeller J. 2002. Growing Up with Television: Everyday Learning Among Young Adolescents. Philadelphia: Temple Univ. Press

Fishman M. 1980. Manufacturing the News. Austin: Univ. Tex. Press

Fiske J. 1987. Television Culture. London/New York: Routledge

Fiske J, Hartley J. 1978. Reading Television. London: Methuen

Foster R, McChesney R, eds. 2004. Our Unfree Press: 100 Years of Radical Media Criticism. New York: New Press

Fox S. 2005. Digital divisions. Pew/Internet Rep. 1-12. Washington, DC: Pew Internet \& Am. Life Proj.

Fraser N. 1990. Rethinking the public sphere: a contribution to the critique of actually existing democracy. Soc. Text 25/26:5680

Frith S. 1978. Sociology of Rock. London: Constable

Gamson J. 1998. Freaks Talk Back: Tabloid Talk Shows and Sexual Nonconformity. Chicago: Univ. Chicago Press

Gamson J, Latteier P. 2004. Do media monsters devour diversity? Contexts 3(3):26-32

Gans HJ. 1979. Deciding What's News. New York: Vintage

Garnham N. 1990. Capitalism and Communication: Global Culture and the Economics of Information. Newbury Park, CA: Sage

Gauntlett D, Hill A. 1999. TV Living: Television, Culture, and Everyday Life. London/New York: Routledge

Gerbner G, Gross L. 1976. Living with television. J. Commun. 26(2):173-99

Gillespie M. 1995. Television, Ethnicity, and Cultural Change. London/New York: Routledge

Gitlin T. 1978. Media sociology: the dominant paradigm. Theory Soc. 6(2):205-53

Gitlin T. 1980. The Whole World Is Watching: Mass Media in the Making and the Unmaking of the New Left. Berkeley: Univ. Calif. Press

Gitlin T. 1983. Inside Prime Time. New York: Pantheon
Golding P, Murdock G, Schlesinger P, eds. 1986. Communicating Politics: Mass Communications and the Political Process. New York: Holmes \& Meier

Gray A. 1992. Video Playtime: The Gendering of a Leisure Technology. London/New York: Routledge

Gray H. 1995. Watching Race: Television and the Struggle for Blackness. Minneapolis: Univ. Minn. Press

Grindstaff L. 2000. Popular culture. In Encyclopedia of Contemporary American Culture, ed. GW McDonogh, R Gregg, CH Wong, pp. 532-33. London/New York: Routledge

Grindstaff L. 2002. The Money Shot: Trash, Class, and the Making of TV Talk Shows. Chicago: Univ. Chicago Press

Gripsrud J. 1995. The Dynasty Years: Hollywood Television and Critical Media Studies. London: Comedia

Grossberg L, Wartella E, Whiteney C. 1998. MediaMaking: Mass Media in a Popular Culture. Thousand Oaks, CA: Sage

Habermas J. 1989. The Structural Transformation of the Public Sphere: An Inquiry into a Category of Bourgeois Society. Transl. T. Burger, F Lawrence. Cambridge, MA: MIT Press

Hall S. 1980. Encoding/decoding. In Culture, Media, Language, ed. S Hall, D Hobson, A Lowe, P Willis, pp. 128-39. London: Hutchinson

Hamamoto DY. 1994. Monitored Peril: Asian Americans and the Politics of TV Representation. Minneapolis: Univ. Minn. Press

Haralovich MB, Rabinovitz L, eds. 1999. Television, History, and American Culture. Durham, NC: Duke Univ. Press

Harrington CL, Bielby D. 1995. Soap Fans: Pursuing Pleasures and Making Meaning in Everyday Life. Philadelphia: Temple Univ. Press

Hartley J. 1999. Uses of Television. London/New York: Routledge

Herman ES, Chomsky N. 1988 (2002). Manufacturing Consent: The Political Economy of the Mass Media. New York: Pantheon Books 
Hill A. 2002. Big Brother: the real audience. Telev. New Media 3(3):323-39

Hills M. 2002. Fan Cultures. London/New York: Routledge

Hirsch PM. 1977. Occupational, organizational and institutional models in mass communication. In Strategies for Communication Research, ed. PM Hirsch, PV Miller, FG Kline, pp. 13-42. Beverly Hills, CA: Sage

Hirsch PM. 2000. Cultural industries revisited. Organ. Sci. 11(3):356-61

Hobson D. 1982. Crossroads: The Drama of a Soap Opera. London: Methuen

Hoynes W. 1994. Public Television for Sale: Media, the Market, and the Public Sphere. Boulder, CO: Westview

Hoynes W. 2002. Political discourse and the "New PBS." Harv. Intern. J. Press/Polit. 7(4):34-56

Iyengar S. 1991. Is Anyone Responsible? How Television Frames Political Issues. Chicago: Univ. Chicago Press

Iyengar S, Kinder D. 1987. News That Matters. Chicago: Univ. Chicago Press

Jenkins H. 1992. Textual Poachers: Television Fans and Participatory Culture. London/New York: Routledge

Jhally S, Lewis J. 1992. Enlightened Racism: The Cosby Show, Audiences, and the Myth of the American Dream. Boulder, CO: Westview

Kannis P. 1991. Making Local News. Chicago: Univ. Chicago Press

Kaplan EA, ed. 1983. Regarding Television. Los Angeles: Am. Film Inst.

Katz E, Dayan D. 1992. Media Events: The Live Broadcasting of History. Cambridge, MA: Harvard Univ. Press

Keane J. 1995. Structural transformations of the public sphere. Commun. Rev. 1(1):1-22

Kellner D. 1981. Network television and American society: introduction to a critical theory of television. Theory Soc. 10(1):3162

Kellner D. 1990. Television and the Crisis of Democracy. Boulder, CO: Westview

Kellner D. 1995. Media Culture: Cultural Studies, Identity, and Politics Between the Mod- ern and the Postmodern. London/New York: Routledge

Kendall D. 2005. Framing Class: Media Representations of Wealth and Poverty in America. Lanham, MD: Rowman \& Littlefield

Klaehn J. 2002. A critical review and assessment of Herman and Chomsky's propaganda model. Eur. J. Commun. 18(3):14782

LeBesco K. 2004. Got to be real: mediating gayness on Survivor. See Murray \& Ouellette 2004, pp. 271-87

Le Bon G. 1908 (1952). The Crowd. London: Benn

Lembo R. 2000. Thinking Through Television. Cambridge MA: Cambridge Univ. Press

Liebes T, Katz E. 1990. Th. Export of Meaning: Cross-Cultural Readings of "Dallas." New York: Oxford Univ. Press

Livingstone S. 1990. Making Sense of Television. London: Pergamon

Livingstone S, Lunt P. 1994. Talk on Television: Audience Participation and Public Debate. London/New York: Routledge

Lull J. 1990. Inside Family Viewing: Ethnographic Research on Television Audiences. London: Routledge

Magder T. 2004. The end of TV 101: reality programs, formats, and the new business of television. See Murray \& Ouellette 2004, pp. $137-56$

Manga J. 2003. Talking Trash: The Cultural Politics of Daytime TV Talk Shows. New York: NY Univ. Press

Mayer V. 2003. Producing Dreams, Consuming Youth: Mexican Americans and Mass Media. New Brunswick, NJ: Rutgers Univ. Press

McCarthy A. 2001. Ambient Television. Durham, NC: Duke Univ. Press

McChesney RW. 1992. Telecommunications, Mass Media and Democracy. New York: Oxford Univ. Press

McChesney RW. 1999. Rich Media, Poor Democracy: Communication Politics in Dubious Times. Urbana: Univ. Ill. Press

McChesney RW. 2004. The Problem of the Media: US Communication Politics in the 21st Century. New York: Monthly Review 
McChesney RW, Newman R, Scott B, eds. 2005. The Future of Media: Resistance and Reform in the $21^{\text {st }}$ Century. New York: Seven Stories

McDonald D. 1968. A theory of mass culture. In Mass Media and Mass Man, ed. A Casty, pp. 12-23. New York: Holt, Rinehart, \& Winston

McLuhan M. 1964. Understanding Media: The Extensions of Man. New York: McGraw-Hill

Mellencamp P. 1990. Logics of Television: Essays in Cultural Criticism. Bloomington: Indiana Univ. Press

Meyrowitz J. 1985. No Sense of Place: The Impact of Electronic Media on Social Behavior. New York: Oxford Univ. Press

Miller MC. 1988. Boxed In: The Culture of TV. Evanston, IL: Northwest. Univ. Press

Miller T, Govil N, McMurria J, Maxwell R. 2001. Global Hollywood. London: Br. Film Inst.

Mintz B, Schwartz M. 1985. The Power Structure of American Business. Chicago: Univ. Chicago Press

Modleski T. 1982. Loving With a Vengeance: Mass Produced Fantasies for Women. London: Methuen

Molotch H, Lester M. 1974. News as purposive behavior. Am. Sociol. Rev. 39:10112

Montgomery K. 1989. Target: Prime Time: Advocacy Groups and the Struggle Over Entertainment Television. New York: Oxford Univ. Press

Morley D. 1980. The "Nationwide" Audience: Structure and Decoding. London: Br. Film Inst.

Morley D. 1986. Family Television. London: Comedia

Morley D. 2004. At home with television. See Spigel \& Olsson 2004, pp. 303-23

Morley D, Silverstone R. 1990. Domestic communications: technologies and meanings. Media Cult. Soc. 12(1):31-55

Mosco V, Schiller D. 2001. Continental Order? Lanham, MD: Rowman \& Littlefield

Murray S, Ouellette L, eds. 2004. Reality TV: Remaking Television Culture. New York: New York Univ. Press
Neale S, Krutnik F. 1990. Popular Film and Television Comedy. London/New York: Routledge

Negt O, Kluge A. 1993. Public Sphere and Experience: Toward an Analysis of the Bourgeois and Proletarian Public Sphere. Minneapolis: Univ. Minn. Press

Newcomb H. 1974. TV: The Most Popular Art. New York: Anchor Press

Newcomb H, ed. 2000. Television: The Critical View. New York: Oxford Univ. Press. 6th ed.

Newcomb H, Hirsch PM. 1983. Television as cultural forum: implications for research. $Q$. Rev. Film Stud. 8(2):45-55

Palmer P. 1986. The Lively Audience: A Study of Children Around the TV Set. Sydney: Allen \& Unwin

Parenti M. 1992. Make-Believe Media: The Politics of Entertainment. New York: St. Martin's Press

Park RE. 1972. The Crowd and the Public and Other Essays, ed. H Eisner Jr. Chicago: Univ. Chicago Press

Parks L. 2004. Flexible microcasting: gender, generation and television-Internet convergence. See Spigel \& Olsson 2004, pp. 133-56

Parks L, Kumar S. 2003. Planet TV: A Global Television Reader. New York: NY Univ. Press

Peterson RA. 1997. Creating Country Music: Fabricating Authenticity. Chicago: Univ. Chicago Press

Peterson RA, Anand N. 2004. The production of culture perspective. Annu. Rev. Sociol. 30:311-34

Peterson RA, Berger DG. 1975. Cycles of symbol production: the case of popular music. Am. Sociol. Rev. 40:158-73

Postman N. 1985. Amusing Ourselves to Death: Public Discourse in the Age of Show Business. New York: Penguin Books

Powell WW. 1985. Getting Into Print. Chicago: Univ. Chicago Press

Press AL. 1991. Women Watching Television: Gender, Class, and Generation in the American Television Experience. Philadelphia: Univ. Penn. Press

Radway J. 1988. Reception study: ethnography 
and the problems of dispersed audiences and nomadic subjects. Cult. Stud. 2(3):359-76

Schiller D. 1999. Digital Capitalism: Networking and the Global Market System. Cambridge, MA: MIT Press

Schiller H. 1969. Mass Communication and American Empire. New York: Kelley

Schiller H. 1989. Culture, Inc.: The Corporate Takeover of Public Expression. New York: Oxford Univ. Press

Scott J. 1979. Corporations, Classes and Capitalism. London: Hutchinson

Seiter E. 2000. Qualitative audience research. See Allen \& Hill 2004, pp. 461-78

Shattuc J. 1997. The Talking Cure: TV Talk Shows and Women. London/New York: Routledge

Sigal LV. 1973. Reporters and Officials: The Organization and Politics of Newsmaking. New York: DC Heath

Silverstone R. 1994. Television and Everyday Life. London/New York: Routledge

Spigel L. 1992. Make Room For TV: Television and the Family Ideal in Postwar America. Chicago: Univ. Chicago Press

Spigel L. 2004. Introduction. See Spigel \& Olssen 2004, pp. 1-34.

Spigel L, Mann D, eds. 1992. Private Screenings: Television and the Female Consumer. Minneapolis: Univ. Minn. Press

Spigel L, Olsson J, eds. 2004. Television After TV: Essays on a Medium in Transition. Durham, NC: Duke Univ. Press

Straubhaar JD. 1991. Beyond media imperialism: asymmetrical interdependence and cultural proximity. Crit. Stud. Mass Commun. 8:39-59
Timberg BM, Erler RJ, Newcomb H, Erler B, eds. 2002. Television Talk: A History of the TV Talk Show. Austin: Univ. Tex. Press

Tuchman G. 1978. Making News: A Study in the Construction of Reality. New York: Free Press

Tulloch J. 2000. Watching Television Audiences: Cultural Theories and Methods. London: Arnold

Tulloch J, Jenkins H. 1995. Science Fiction Audiences: Watching 'Dr. Who' and 'Star Trek.' London/New York: Routledge

Turow J. 1978. Casting for television: the anatomy of social typing. J. Commun. 28(4):18-24

Turow J. 1984. Media Industries: The Production of News and Entertainment. New York: Longman

Turow J. 1989. Playing Doctor. New York: Oxford Univ. Press

Turow J. 2005. Audience construction and culture production: marketing surveillance in the digital age. Ann. Am. Acad. Polit. Soc. Sci. 597:103-21

Turow J. 2006. Niche Envy: Marketing Discrimination in the Digital Age. Cambridge, MA: MIT Press

Uricchio W. 2004. Television's next generation: technology/interface culture/flow. See Spigel \& Olsson 2004, pp. 163-82

Williams R. 1974. Television: Technology and Cultural Form. London: Wesleyan Univ. Press

Wilson P. 2004. Jamming Big Brother: webcasting, audience intervention, and narrative activism. See Murray \& Ouellette 2004, pp. 323-43 
内

Annual Review of Sociology

Volume 32, 2006

\section{Contents}

Frontispiece-Robin M. Williams, Jr.

\section{Prefatory Chapter}

The Long Twentieth Century in American Sociology: A

Semiautobiographical Survey, Robin M. Williams, Jr.

\section{Social Processes}

Sociological Theories of Human Emotions, Jonathan H. Turner and Jan E. Stets

Legitimacy as a Social Process, Cathryn Johnson, Timothy J. Dowd, and Cecilia L. Ridgeway

Estimating the Causal Effect of Social Capital: A Review of Recent Research, Ted Mouw

Institutions ANd Culture

Video Cultures: Television Sociology in the "New TV" Age, Laura Grindstaff and Joseph Turow

The Rise of Religious Fundamentalism, Michael O. Emerson and David Hartman

\section{Formal Organizations}

Community Ecology and the Sociology of Organizations, John H. Freeman and Pino G. Audia

Organizational Restructuring and its Consequences: Rhetorical and Structural, Paul M. Hirsch and Michaela De Soucey

\section{Political and Economic Sociology}

Voters, Satisficing, and Policymaking: Recent Directions in the Study of Electoral Politics, Clem Brooks

Law and the American State, John D. Skrentny

The Social Bases of Political Divisions in Post-Communist Eastern Europe, Geoffrey Evans 


\section{Differentiation and STRatification}

Cumulative Advantage as a Mechanism for Inequality: A Review of Theoretical and Empirical Developments, Thomas A. DiPrete and Gregory M. Eirich

New Approaches to Understanding Racial Prejudice and Discrimination, Lincoln Quillian

\section{INDIVIDUAL AND SOCIETY}

The Science of Human Rights, War Crimes, and Humanitarian Emergencies, John Hagan, Heather Schoenfeld, and Alberto Palloni

Problems and Prospects in the Study of Physician-Patient Interaction: 30 Years of Research, John Heritage and Douglas W. Maynard

\section{DEMOGRAPHY}

Low Fertility at the Turn of the Twenty-First Century, S. Philip Morgan and Miles G. Taylor

Sons, Daughters, and Family Processes: Does Gender of Children Matter? Sara Raley and Suzanne Bianchi

\section{Urban and Rural Community Sociology}

The Texture of Hardship: Qualitative Sociology of Poverty, 1995-2005, Katherine S. Newman and Rebekah Peeples Massengill

\section{Sociology and World Regions}

Globalization of Law, Terence C. Halliday and Pavel Osinsky

\section{INDEXES}

Subject Index

Cumulative Index of Contributing Authors, Volumes 23-32

Cumulative Index of Chapter Titles, Volumes 23-32

\section{ERrata}

An online log of corrections to Annual Review of Sociology chapters (if any, 1997 to the present) may be found at http://soc.annualreviews.org/errata.shtml 